\title{
Initial Opening of the Eurasian Basin, Arctic Ocean
}

\author{
Kai Berglar*, Dieter Franke, Rüdiger Lutz, Bernd Schreckenberger and Volkmar Damm \\ Federal Institute for Geosciences and Natural Resources (BGR), Hannover, Germany
}

Analysis of the transition from the NE Yermak Plateau into the oceanic Eurasian Basin sheds light on the Paleocene formation of this Arctic basin. Newly acquired multichannel seismic data with a $3600 \mathrm{~m}$ long streamer shot during ice-free conditions enables the interpretation of crustal structures. Evidence is provided that no major compressional deformation affected the NE Yermak Plateau. The seismic data reveal that the margin is around $80 \mathrm{~km}$ wide and consists of rotated fault blocks, major listric normal faults, and half-grabens filled with syn-rift sediments. Taking into account published magnetic and gravimetric data, this setting is interpreted as a rifted continental margin, implying that the NE Yermak Plateau is of continental origin. The transition from the Yermak Plateau to the oceanic Eurasian Basin might be located at a prominent basement high, probably formed by exhumed mantle. In contrast to the Yermak Plateau margin, the North Barents Sea continental margin shows a steep continental slope with a relatively abrupt transition

OPEN ACCESS

Edited by:

Øyvind Engen,

Statoil ASA, Norway

Reviewed by:

Valerio Acocella,

Roma Tre University, Italy

Deborah R. Hutchinson,

United States Geological Survey, USA

*Correspondence:

Kai Berglar

kai.berglar@bgr.de

Specialty section:

This article was submitted to Structural Geology and Tectonics,

a section of the journal

Frontiers in Earth Science

Received: 24 February 2016 Accepted: 05 October 2016

Published: 21 October 2016

Citation:

Berglar K, Franke D, Lutz R, Schreckenberger B and Damm V (2016) Initial Opening of the Eurasian

Basin, Arctic Ocean.

Front. Earth Sci. 4:91.

doi: 10.3389/feart.2016.00091 to the oceanic domain. Based on our limited data, we propose a working hypothesis speculating that the initial opening direction of the Eurasian Basin in the Arctic Ocean was highly oblique to the present day seafloor spreading direction.

Keywords: Yermak Plateau, Nansen Basin, Arctic Ocean, magma-poor rifting, continent-ocean transition, exhumed mantle, reflection seismic data

\section{INTRODUCTION}

Two major oceanic basins are found in the Arctic Ocean (Figure 1). While the origin and evolution of the Amerasian Basin is still under discussion, the general evolution of the Eurasian Basin is much better known (e.g., Lawver et al., 2011; Shephard et al., 2013). Well-defined magnetic seafloor spreading anomalies in the Eurasian Basin of the Arctic Ocean from C24 and younger are merely undisputed (Srivastava and Tapscott, 1986; Lawver et al., 2002; Brozena et al., 2003). Accordingly, it is widely accepted that the continental Lomonosov Ridge (Figure 1), a major bathymetric elevation, separating the Eurasian from the Amerasian Basin (Jokat et al., 2013) was split off the Eurasia continent and migrated northward to its present position since $\sim 53 \mathrm{Ma}$ (e.g., Alvey et al., 2008). The Lomonosov Ridge previously might have formed a continuous structure with the Yermak Plateau (Figure 1) but the crustal nature of this major submarine plateau at the North Barents Sea continental margin is under debate (Jackson et al., 1984; Jokat et al., 2008; Geissler et al., 2011). This comes along with a considerable dispute, particularly about the earliest, Paleocene evolution of the Eurasian Basin. The split off of the elongated and about $1500 \mathrm{~km}$ long crustal splinter of the Lomonosov Ridge from the North Barents Sea continental margin and its eastern prolongation, the Kara Sea continental margin, is difficult to be explained with current rifting models. An episode of shear or oblique extension has been suggested before breakup to explain the observed narrow symmetric conjugate margins in the Eurasia Basin (Minakov et al., 2012, 2013). 


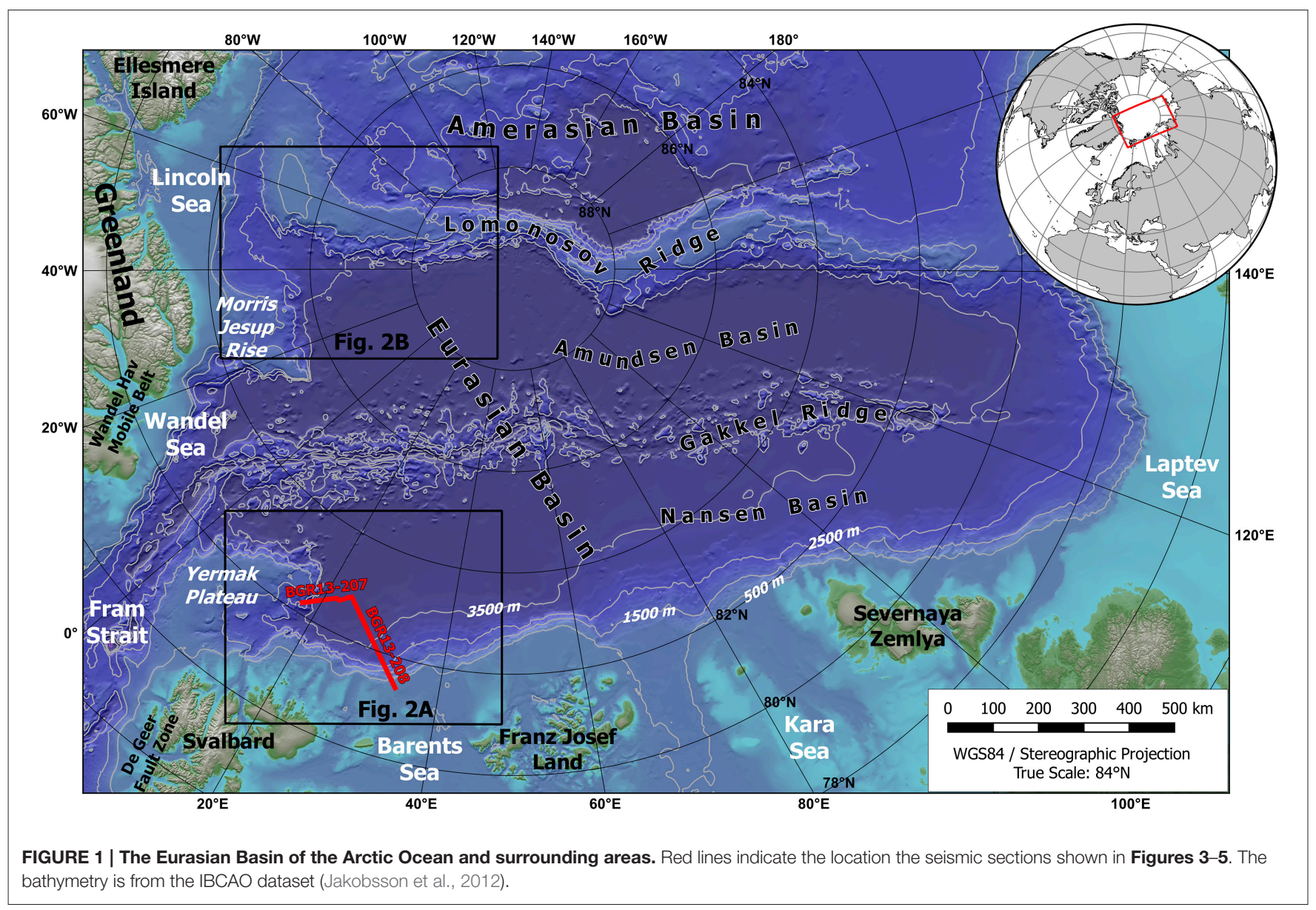

In addition, different interpretations are at hand about the presence of magnetic anomaly C25 (e.g., Brozena et al., 2003; Engen et al., 2008). A problem with this magnetic anomaly is that it may overlap with a major strike-slip fault east of the Yermak Plateau that is thought to have accommodated the northward migration of the Lomonosov Ridge. The presence of such a fault has been suggested on the basis of potential field data (e.g., Brozena et al., 2003). In addition, in settings with minor magma supply it is questionable if there is a sharp contact between continental and oceanic crust. As shown by Bronner et al. (2011) offshore Iberia there is a gradual transition from continental crust, to exhumed mantle, to oceanic crust and pulses of magmatism at breakup can generate anomalies that may be misinterpreted as magnetic seafloor spreading anomalies. The situation is further complicated by the Late Paleocene and early-middle Eocene compressional deformation (Eurekan) that affected wide portions of the Svalbard archipelago (e.g., Eldholm et al., 1987) and may have deformed the junction between the Yermak Plateau and the Eurasian Basin (Brozena et al., 2003; Døssing et al., 2013).

The NE Yermak Plateau and the North Barents Sea continental margin are poorly investigated areas because the nearly permanent ice cover hampers scientific investigations. In this study, newly acquired multichannel seismic reflection (MCS) data, supplemented by potential field data, are used to study the area of the eastern Yermak Plateau, the adjacent Eurasian Basin, and the North Barents Sea continental margin. Structural data reveal the margins architecture and allow speculations about the rifting and break-up of the Eurasian Basin at the junction of the Yermak Plateau with the North Barents Sea continental margin. This study shows that neither subduction nor substantial transpression affected the eastern Yermak Plateau. Rather it is suggested, that the initial extension of the Eurasian Basin took place between the Yermak Plateau and the Lomonosov Ridge at a high angle to the present day orientation of spreading.

\section{GEOLOGICAL SETTING}

\section{Eurasian Basin of the Arctic Ocean}

During Cretaceous times, North America, Greenland, and Eurasia, including the Lomonosov Ridge and Svalbard, were part of the common land mass of Laurasia. The oldest magnetic anomaly consistently interpreted along the margins of Eurasia and Greenland within the North Atlantic is C24 (e.g., Gaina et al., 2009) with an age of $\sim 53 \mathrm{Ma}$ from the Paleocene-Eocene transition according to the time-scale after Gee and Kent (2007), which we use in this study. In the Eurasian Basin, Vogt et al. (1979) discussed the possibility of the presence of magnetic anomalies older than C24. However, they did not present a conclusive interpretation in between the North Barents Sea 
continental margin and magnetic anomaly C24. Several recent magnetic anomaly interpretations and plate models favor the presence of magnetic chron C25 (Brozena et al., 2003; Cochran et al., 2006; Døssing et al., 2014) with an age of $~ 56 \mathrm{Ma}$ from the Late Paleocene. Brozena et al. (2003) identified anomalies C25 to C15 (56-34.8 Ma) terminating shortly before the NE Yermak Plateau and Morris Jesup Rise flanks, anomalies C12C8 (30.8-25.9 Ma) spreading apart of the plateaus and extending for another $60-90 \mathrm{~km}$ to the SW, and anomaly C5 $(9.8 \mathrm{Ma})$ continuing into the Fram Strait. This interpretation has been widely confirmed by Engen et al. (2008), although they do not interpret the existence of anomaly C25 in the Eurasian Basin. Here, we refer to the interpretation of Brozena et al. (2003). If indeed magnetic anomaly C25 is present in the Eurasian Basin (Brozena et al., 2003) then about $150 \mathrm{~km}$ of oceanic crust was created between the Lomonosov Ridge and the Eurasian margin by magnetic chron C24. This is in accordance with structural investigations, where, from the location of the transition to oceanic crust, and by assuming a spreading half-rate of $1 \mathrm{~cm} / \mathrm{yr}$, Geissler and Jokat (2004) calculate that seafloor spreading in the Eurasian Basin close to the Yermak Plateau started about $5 \mathrm{Ma}$ before magnetic chron C24.

Close to the Yermak Plateau the magnetic isochrons C25 and C24 change direction from east-west to southwest-northeast (Brozena et al., 2003; Figure 2A). More prominently, this trend is observed in the magnetic data between the Morris Jesup Rise and the Lomonosov Ridge in the Lincoln Sea (Figure 2B), and is mirrored by gravity data (Døssing et al., 2014). Thus, the earliest magnetic chrons show an extension direction that, close to the Yermak Plateau and Morris Jesup Rise, considerably deviates from the younger chrons. On the Siberian side of the Eurasian Basin, the oldest anomaly is tentatively interpreted as chron C24 (Glebovsky et al., 2006). These observations imply that the opening of the Eurasian Basin commenced on the European side, and might have propagated toward the Siberian side (Cochran et al., 2006) where a major continental rift developed at the shelf, the Laptev Sea Rift (e.g., Franke and Hinz, 2005).

Seafloor spreading in the Eurasian Basin resulted in separation of a narrow continental microplate (Jokat et al., 2013), the Lomonosov Ridge, from the northeastern margin of Eurasia (Lawver et al., 2002; Gaina et al., 2009) - either as a part of the North American plate (Srivastava, 1985) or as an independent plate. Before the opening of the Eurasian Basin, the Lomonosov Ridge was located directly along the North Barents Sea continental margin, with the ridge's western end adjacent to the ancestral Yermak Plateau and Morris Jesup Rise (Brozena et al., 2003).

Prior to Oligocene times, the Yermak Plateau and the Morris Jesup Rise formed a contiguous plateau (Feden et al., 1979; Jackson et al., 1984; Engen et al., 2008), which has been placed northeast of Greenland, when reconstructed (e.g., Srivastava, 1985; Srivastava and Tapscott, 1986; Tessensohn and Piepjohn, 2000). Jointly with the opening of the North Atlantic, Late Paleocene plate motions led to a dextral transcurrent transfer of Svalbard, and probably also the Yermak Plateau and the Morris Jesup Rise, relative to north Greenland (e.g., Srivastava, 1985; Srivastava and Tapscott, 1986; von Gosen and Piepjohn,
2003; Tessensohn et al., 2008). However, not only strike-slip and extensional deformation occurred during the early Paleocene, but also compressional deformation. Late Paleocene and earlymiddle Eocene compression (Eurekan) north of the evolving North Atlantic Ocean basin created the West Svalbard fold belt (Eldholm et al., 1987). From a geometrical point of view, the Morris Jesup Rise and Yermak Plateau should have experienced the same compressional phase, and Døssing et al. (2013) suggest that significant Eurekan transpression, or possibly subduction (Brozena et al., 2003), took place along the boundary between the Morris Jesup Rise and the Yermak Plateau and the Eurasian Basin.

The youngest evolution of the area is merely undisputed. At 33-35 Ma, the conjugate Yermak Plateau and the Morris Jesup Rise started to break up by SW propagation of seafloor spreading-and magnetic anomaly C7 $(24.8 \mathrm{Ma})$ is the oldest anomaly pair completely separating the two plateaus (Eldholm et al., 1987; Brozena et al., 2003; Engen et al., 2008; Geissler et al., 2011).

\section{Yermak Plateau and Morris Jesup Rise}

The crustal fabric of the Yermak Plateau and its conjugate, the Morris Jesup Rise, is not yet fully clear. However, the early interpretation that the plateaus were completely generated by massive extrusions of basalt during the lower and middle Tertiary, and that the origin of this basalt is related to hotspot activity (Feden et al., 1979), has been challenged in recent years. Seismic velocities of the acoustic basement underlying the southern portions of the Yermak Plateau were interpreted by Jackson et al. (1984) as thinned continental crust due to Pwave velocities between $\sim 4.3$ and $6.0 \mathrm{~km} / \mathrm{s}$. In the northeastern portion of the Yermak Plateau, Jackson et al. (1984) suggested the presence of over-thickened oceanic crust. In the western portion of the Yermak Plateau, up to $82^{\circ} \mathrm{N}$, a crust with continental affinities has been inferred from seismic velocities (Ritzmann and Jokat, 2003) and also from the structural grain as derived from a dense grid of reflection seismic data (Jokat et al., 2008). Jokat et al. (2008) confirm that the southern and northwestern Yermak Plateau are made up of attenuated and locally intruded continental crust, based on preserved structures on the Yermak Plateau resulting from the strike-slip movements between North Greenland and Svalbard. Relatively weak magnetic anomalies over this area (Feden et al., 1979), and gravity modeling, support this interpretation and show that the southern Yermak Plateau consists of thinned, $\sim 20$ to $25 \mathrm{~km}$ thick continental crust (Geissler and Jokat, 2004). Based on sonobuoy-derived P-wave velocities, Geissler et al. (2011) speculate that the northern basement highs on the central Yermak Plateau are the continuation of Paleozoic Svalbard geology, or alternatively, were once part of the Cretaceous shelf in front of the northern tip of Greenland. From the sedimentary cover, these authors also propose that the acoustic basement of the plateau should be older than 33-35 Ma. This view was confirmed by Riefstahl et al. (2013) who suggest from analyzed dredge samples that the basement highs on the central Yermak Plateau consist of thinned continental crust of pre-Devonian age, forming a direct continuation of 


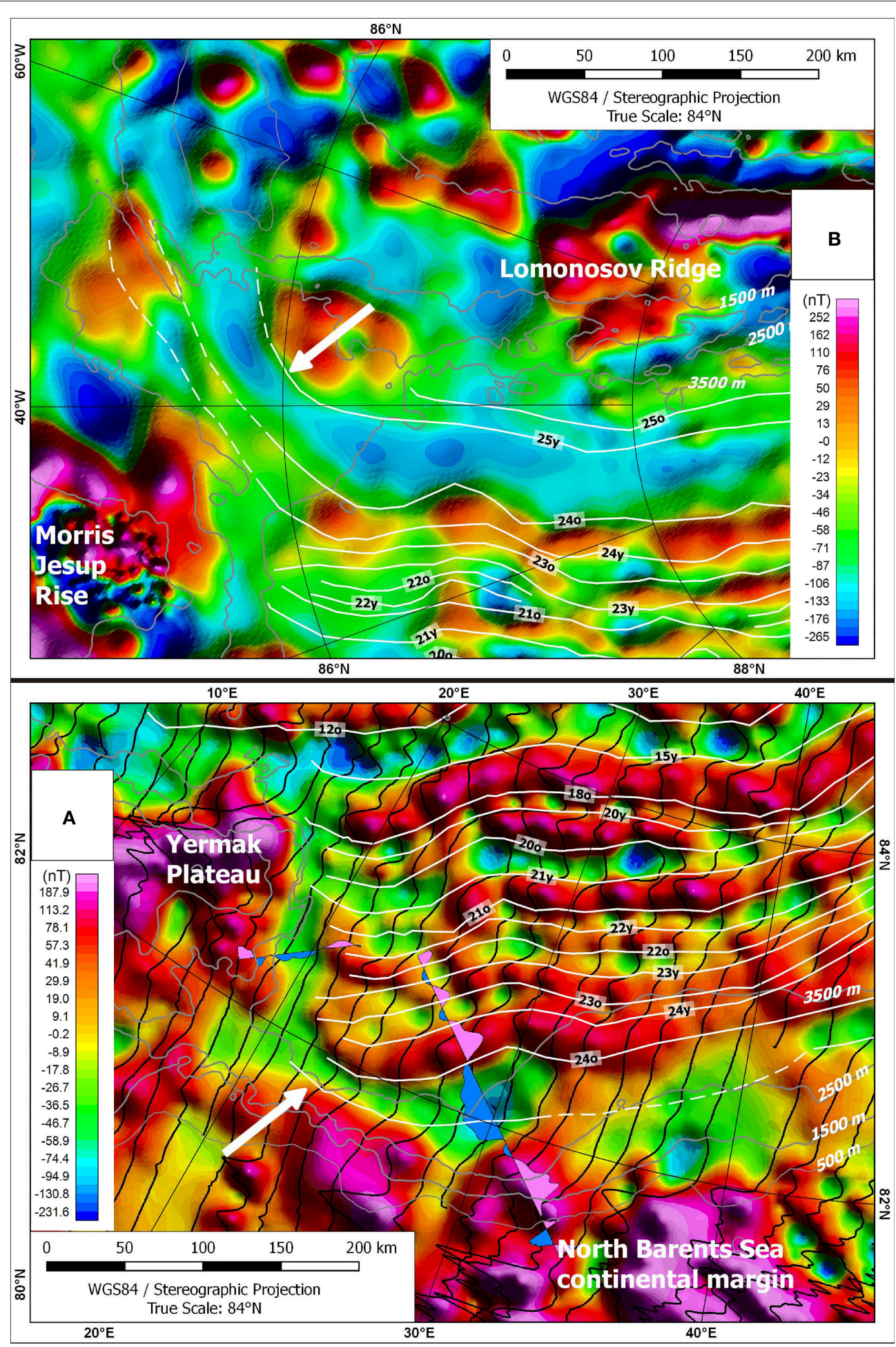

FIGURE 2 | Magnetic anomaly maps of the western Eurasian Basin with superimposed anomaly interpretation from Brozena et al. (2003, white lines). White arrows indicate the northward bending of anomalies C25? and C24, gray lines the bathymetry from the IBCAO dataset (Jakobsson et al., 2012). (A) Newly gridded aeromagnetic line data (US Naval Research Laboratory Arctic surveys 1998/99, Brozena et al. (2003), downloaded from NCEI/NOAA) and raw data used for gridding (black wiggle traces). Also shown are the magnetic data measured along lines BGR13-207 and -208 as filled wiggle traces (see also Figure 3B). (B) Data from the CampGM compilation (Gaina et al., 2011). 
the exposures on northern Svalbard. According to Riefstahl et al. (2013), the stretched continental crust has been strongly affected by alkaline magmatism that took place at $\sim 51 \mathrm{Ma}$, and is probably also associated with the high-amplitude magnetic anomalies described in the northeastern Yermak Plateau. Thus, it appears plausible that the major portion of the Yermak Plateau up to $82^{\circ} \mathrm{N}$ is underlain by attenuated continental crust. Also, the basin south of the northeastern Yermak Plateau is characterized as rifted continental crust by Geissler and Jokat (2004). Engen et al. (2008) expanded the interpretation of continental crust and suggested that the outer Yermak Plateau and the conjugate Morris Jesup Rise also represent protrusions of stretched continental crust with high amplitude magnetic anomalies relating to magmatic intrusions. The Bouguer anomaly character of the inner Yermak Plateau continues, according to Engen et al. (2008), into the outer plateau. This is in agreement with a system of normal faults beneath the continental slope in a $15-20 \mathrm{~km}$ wide transitional area to the deep Nansen Basin in the north of the Yermak Plateau (Geissler and Jokat, 2004). One successful dredge at a basement high on the central Yermak Plateau $\left(81^{\circ} 38^{\prime} \mathrm{N} ; 15^{\circ} 32^{\prime} \mathrm{E}\right)$ revealed meta-sedimentary rocks, similar to outcropping lithologies along the northernmost Svalbard coastline (Hellebrand, 2000).

\section{North Barents Sea Continental Margin}

Geissler and Jokat (2004) identified two structural boundaries north of northeastern Svalbard: A hinge zone between the inner and outer shelf; and a system of normal faults beneath the continental slope of the North Barents Sea continental margin. The dislocation in the $15-20 \mathrm{~km}$ wide fault zone, with normal faults dipping at about $20^{\circ}$, reaches values up to $2000 \mathrm{~m}$ (Geissler and Jokat, 2004). Minakov et al. (2012) published a series of crustal-scale transects illustrating the architecture of the margin based on sparse seismic reflection lines and gravity modeling. Their gravity inversion supports a narrow and steep continent-ocean transition. A free-air gravity anomaly in the western part of the margin, close to the Yermak Plateau, is suggested to be caused by the exhumation of the lower crust and the continental upper mantle within the continent-ocean transition. They also suggested that an episode of shear or oblique extension before breakup is required to explain the observed narrow symmetric conjugate margins in the Eurasian Basin.

The conjugate continental margin of the Lomonosov Ridge consists of sets of rotated fault blocks stepping down to the basin over some tens of kilometers (Cochran et al., 2006; Langinen et al., 2009). Cochran et al. (2006) concluded from an extensive study of the Lomonosov Ridge that the continentocean transition zone at the Eurasian flank is much narrower than observed at other magma-poor margins worldwide. Sparse refraction seismic data across the Lomonosov Ridge show an abrupt crustal thinning from more than $25 \mathrm{~km}$ Moho depth beneath the Lomonosov Ridge to $\sim 15 \mathrm{~km}$ in the Amundsen Basin over a few tens of kilometers (e.g., Artyushkov, 2010), a finding that is confirmed by regional gravity inversion (Alvey et al., 2008).

\section{Reflection Seismic and Magnetic Data}

The interpretation presented in this study are based on MCS data, acquired in 2013 during the PANORAMA- 1 cruise of the Federal Institute for Geosciences and Natural Resources (BGR) with the research vessel OGS Explora. We used a $3600 \mathrm{~m}$ streamer with a total of 288 channels and an airgun array of 32.8 liter working on 140 bar. Shot distance was $25 \mathrm{~m}$ with a record length of $10 \mathrm{~s}$. Data processing was carried out in the pre-stack domain including designature, multiple reduction (srme, TauP deconvolution, radon multiple prediction, and subtraction), common reflection surface, Kirchhoff migration, and time variant bandpass filtering. Magnetic data were measured along the reflection seismic lines with a towed gradient magnetometer. This method allows acquisition of variation-corrected data (Roeser et al., 2002).

\section{RESULTS}

The reflection seismic data presented here consist of a composite section running for about $125 \mathrm{~km} \mathrm{SW-NE} \mathrm{from} \mathrm{the} \mathrm{northeastern}$ Yermak Plateau into the Nansen Basin (BGR13-207), and for about $255 \mathrm{~km}$ NW-SE from the Nansen Basin to the North Barents Sea continental margin (BGR13-208) (Figure 1). The data depict the south-westernmost area of the Nansen Basin, which is a key region for understanding the initial opening of the Eurasian Basin, i.e., the detachment of the Lomonosov Ridge from the then adjunct Yermak Plateau and Morris Jesup Rise. They allows us a comparison of the continental margin types of the eastern Yermak Plateau and the North Barents Sea continental margin, as well as an interpretation of the sedimentary units.

\section{Seismic Stratigraphy}

For the sedimentary strata, we adopted the seismic stratigraphic units established by Engen et al. (2009), and tied our data to their interpretation of seismic line NPD-POLAR-16. Engen et al. (2009) divide the sedimentary strata of the Nansen Basin into four main units which we also identified in our seismic data (Figure 3B): Units NB-1A and NB-1B were deposited during the time interval from the opening of the Eurasian Basin until the separation of the Yermak Plateau and Morris Jesup Rise. The sediments of unit NB-1A were deposited during the initial opening, showing onlapping and draping of the underlying basement. This is followed by unit NB-2 deposited during the opening of the Fram Strait, which was the last major plate tectonic event before the establishment of the present regime in this area. Unit NB-3 represents sediments from this time until the onset of intensified glaciomarine deposition at about 2.6 Ma (Engen et al., 2009), named units NB-4A and NB-4B.

Next to the Yermak Plateau, we identified in addition the sedimentary unit NB-0 (Figure 4), underlying unit NB-1A. It is bounded at the top by a distinct unconformity, and the overlying reflectors of unit NB-1A onlap this unconformity. The maximum thickness is about $1.5 \mathrm{~s}$ (TWT), and this unit is characterized by a hummocky to contorted reflection pattern with upwards increasing continuity. Below unit NB0 , distinct southwest dipping reflectors indicate the top of 


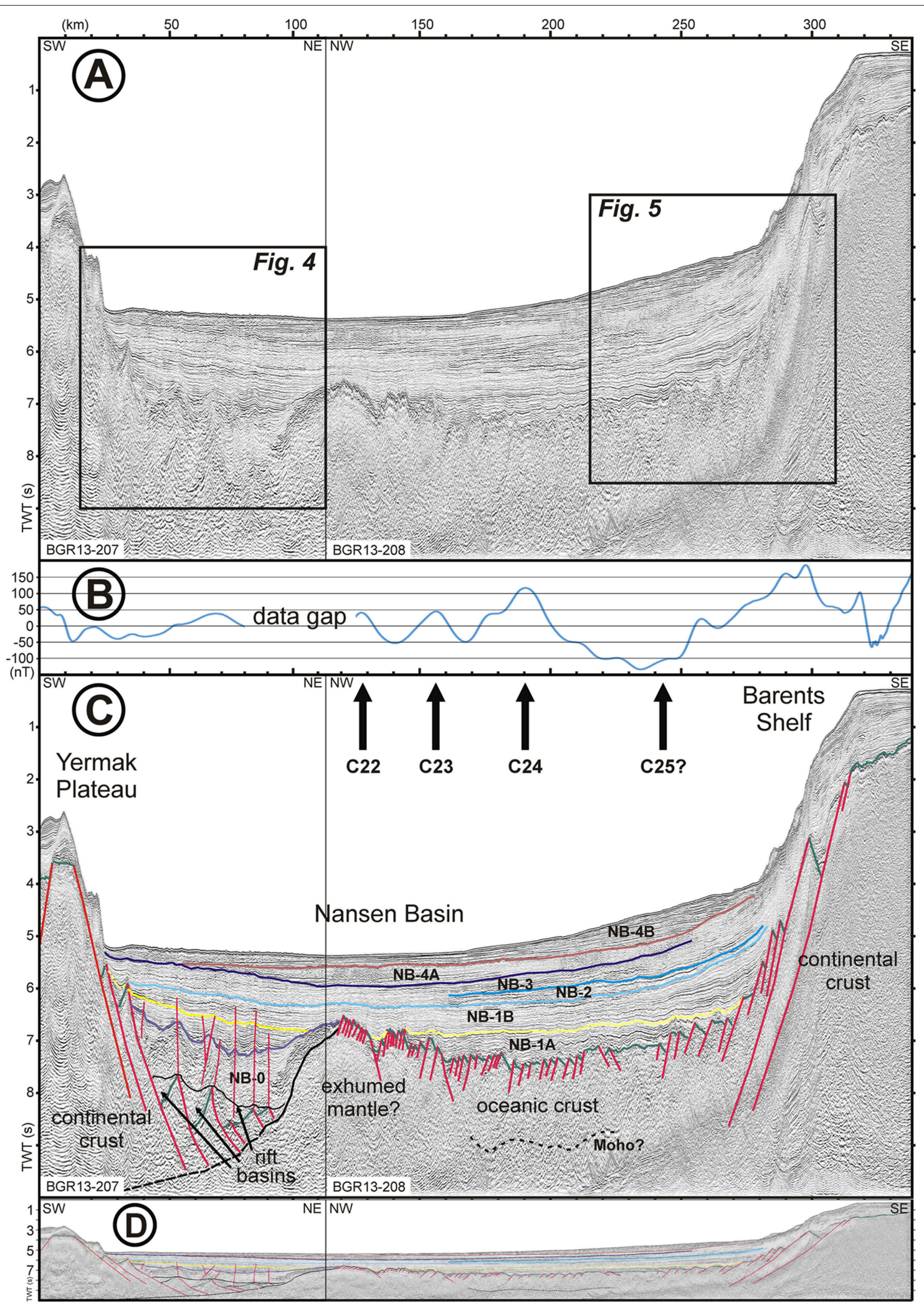

FIGURE 3 | Composite MCS line depicting the northeastern Yermak Plateau, the southwestern part of the Nansen Basin, and the North Barents Sea continental margin. The location is shown in Figure 1. (A) Reflection seismic sections BGR13-207 and -208. (B) Magnetic data measured along the composite MCS line. Data gap is present because of instrument recovery due to ice conditions. (C) Interpreted section with magnetic anomaly identifications from Brozena et al. (2003). At the line tie a basement high with distinct high amplitude reflections might be exhumed mantle material. The transition to the Barents Shelf is comparatively narrow and steep. (D) Interpreted section with lower vertical exaggeration $(\sim 3)$ to better depict the geometry of the basement structures. 


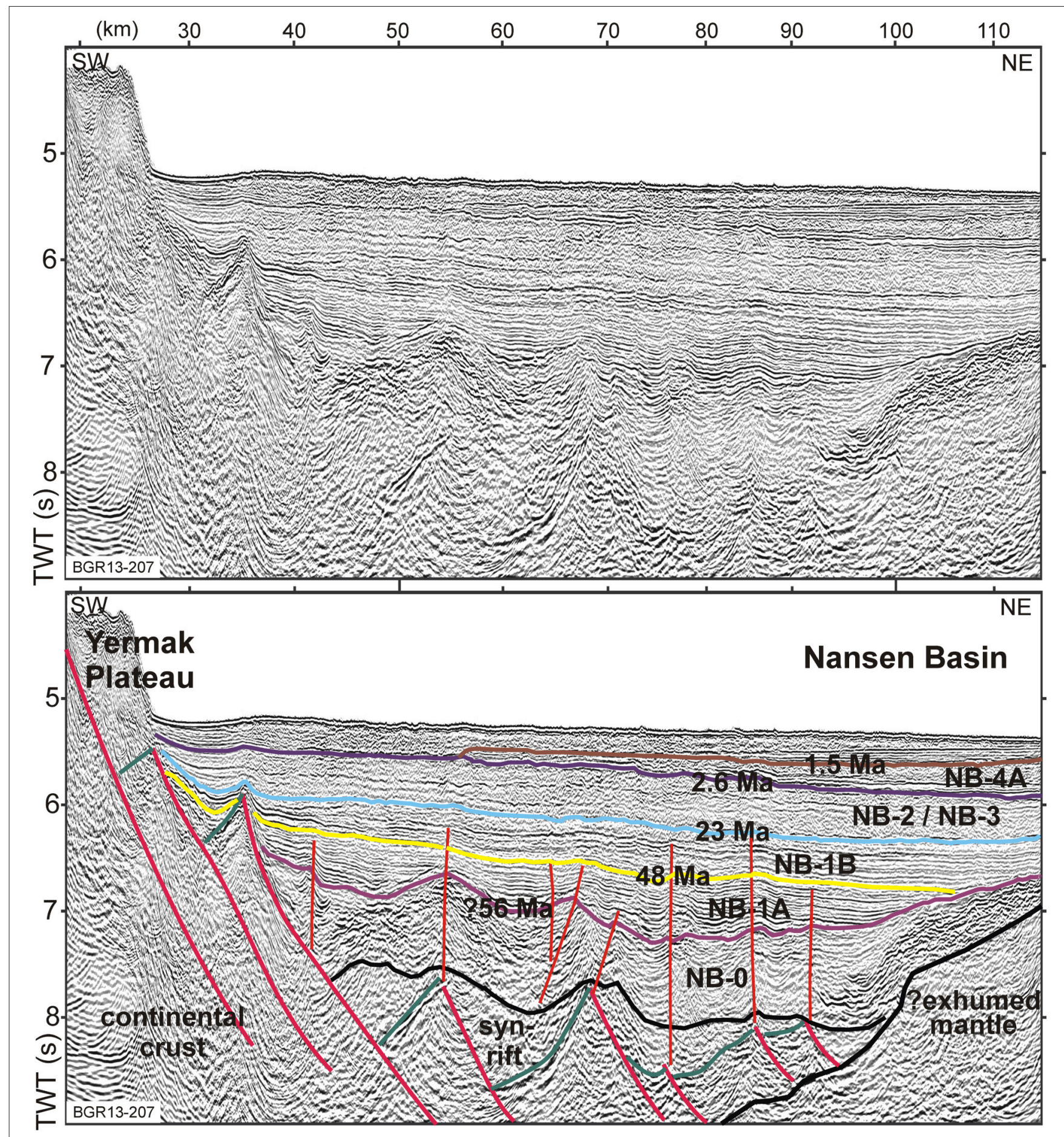

FIGURE 4 | Zoom of the continental margin east of the Yermak Plateau shown in Figure 3. Rift basins developed above rotated basement blocks which are covered by unit NB-0, indicating later subsidence. The steep faults above, affecting units NB-0, NB-1A, and NB1-B, with upwards decreasing deformation, are caused by a transpressional regime ending during deposition of unit NB-1B.

rotated fault blocks forming half grabens. These half grabens are filled by the wedge-shaped unit "syn-rift" (Figure 4), characterized by a contorted reflection pattern. This unit is bounded at the top by an unconformity indicated by toplaps visible in some places (e.g., Figure 4, km 45-55). Smallerscale compressional faulting affects the sedimentary units from unit "syn-rift" to unit NB-1B, with upwards decreasing intensity. 


\section{Structural Interpretation}

From the west to the east we divide the composite section into three characteristic basement domains (Figure 3A):

(I) The most striking observation at the Yermak Plateau margin is an $\sim 80 \mathrm{~km}$ wide domain of horizontal extension, made up of tilted basement blocks forming half graben structures (Figure 4). The domain is bounded to the west by the Yermak Plateau and to the east by a basement high with a distinct high impedance reflectivity. Using solely multi-channel seismic data, it is difficult to conclusively define the nature of the basement (Klimke et al., in press). However, the fabric of the oceanic crust in the abyssal plain is typically quite distinct from the block-faulted fabric of the continental domain (e.g., Taylor et al., 1999; Franke et al., 2011; Peron-Pinvidic et al., 2013). By analogy with the well-studied magma-poor margins of Iberia (e.g., Whitmarsh et al., 2001; Manatschal, 2004; Peron-Pinvidic et al., 2013), East India (Haupert et al., 2016), the South China Sea (e.g., Cullen et al., 2010; Franke et al., 2014; Ding et al., 2016), and southern Australia (Gillard et al., 2015), we suggest that the basement blocks are of continental origin. The basement blocks decrease in size toward the east, and we interpret these as continental crustal ribbons formed during the break-up of the Yermak Plateau and the Lomonosov Ridge. The detachment is interpreted as running along the top of the structure that forms a basement high further seaward. Thus, the Yermak Plateau margin is interpreted here as a rifted continental domain. An end-rift unconformity may be inferred, which seals the structures that formed during extensional deformation. After rifting, deposition of unit NB-0 indicates a phase of subsidence or sag. Further subsidence is indicated by the onlapping of unit NB-1A. A phase of smaller-scale compressive deformation affected the sedimentary units up to unit NB-1B, with upwards decreasing intensity, at about the Eocene-Oligocene transition, which is interpreted as transpression resulting from the northward movement of the Gakkel Ridge along the Yermak Plateau.

(II) Further to the east into the Nansen Basin, a basement high characterized by high impedance reflectivity is present (Figure 3B, km 110-150). From km 150-240 the basement is slightly deeper and has a lower reflectivity. Brittle deformation of the basement is indicated by small-scale normal faulting. Internal reflectivity is low, and a low frequency reflector about $1.8 \mathrm{~s}$ (TWT) below the basement reflector might represent the seismic Moho (km 170-220), thus indicating thin oceanic crust. The distinct reflectivity of the basement high, and its westward dipping to below tilted basement blocks, suggest an exhumation of mantle material during break-up, similar to that discovered and proved by scientific drilling along the Iberia magmapoor continental margin (e.g., Whitmarsh et al., 2001; Sibuet et al., 2007). Magnetic anomalies (Figures 2A, 3) are interpreted by Brozena et al. (2003) at the location of this proposed exhumed mantle, and might have developed during serpentinization. It is well known that mantle peridotite ridges can acquire significant amounts of magnetization during serpentinization, and can thus mimic linear magnetic anomalies (Sibuet et al., 2007).

(III) The North Barents Sea continental margin is characterized by narrow tilted basement blocks below a steep slope up to the shelf (Figure 5). Deeply penetrating faults are present along the margin at the boundary to the oceanic domain. The basement at the slope exhibits little internal reflectivity (partially because of the crossing of the seafloor multiple). In the seaward direction, disrupted basement blocks developed before the deposition of unit NB-1A (Figures 3, 5, km 240-280). The nature of the basement in this area is unclear. There are no indications for listric faulting or syn-tectonic sedimentation. In combination with the low frequency, high amplitude reflectivity this might indicate mafic or peridodite basement composition. Independent from the basement origin, the seismic data in this area (Figures 3C, 5) reveal that the transition from oceanic to continental crust is narrow: At maximum $40 \mathrm{~km}$ on our line, which runs at an oblique angle to the shelf.

\section{Differences between the North Barents Sea and Yermak Plateau Margins}

In terms of seismic stratigraphy (Figure 6), unit NB-0 is exclusively developed next to the Yermak Plateau (Figure 4). This unit, with a thickness of up to $1.5 \mathrm{~s}$ (TWT, $\sim 3 \mathrm{~km}$ ), covers the rift basins and is, from a confident tracing of the overlying sedimentary successions, interpreted as being significantly earlier deposited than the draping sedimentary units in the study area (Figure 3). This unit has never been deposited on the Barents side, because there are no indications for a large-scale erosion phase. The most distinct difference between the two margins are the large rift basins at the Yermak Plateau, which are missing at the North Barents Sea continental margin. These up to 15 $\mathrm{km}$ wide basins show indications for syn-tectonic sedimentary deposition and are bounded by deeply reaching listric normal faults (Figure 4). Top-lap truncations at the top of the syntectonic infill indicate an erosional phase, as it is widespread found in rift basins. This architecture is completely at odds with the North Barents Sea continental margin, where only a comparatively narrow area has been deformed by horizontal extension, the deformation is small-scale, and no syn-tectonic deposition took place at the slope (Figure 5).

\section{DISCUSSION}

\section{The Eurekan Deformation Did Not Affect the Eastern Yermak Plateau}

At the NE edge of the Yermak Plateau, our data reveal no significant compressional deformation. Rather we identify distinct rotated crustal blocks, interpreted to be bounded by major listric normal faults. Previously, gravity and magnetic anomaly lows immediately northeastward of the Yermak Plateau and Morris Jesup Rise, and trending about perpendicular to the seafloor spreading direction, have been interpreted as a major Eurekan fault zone, involving crustal shortening 


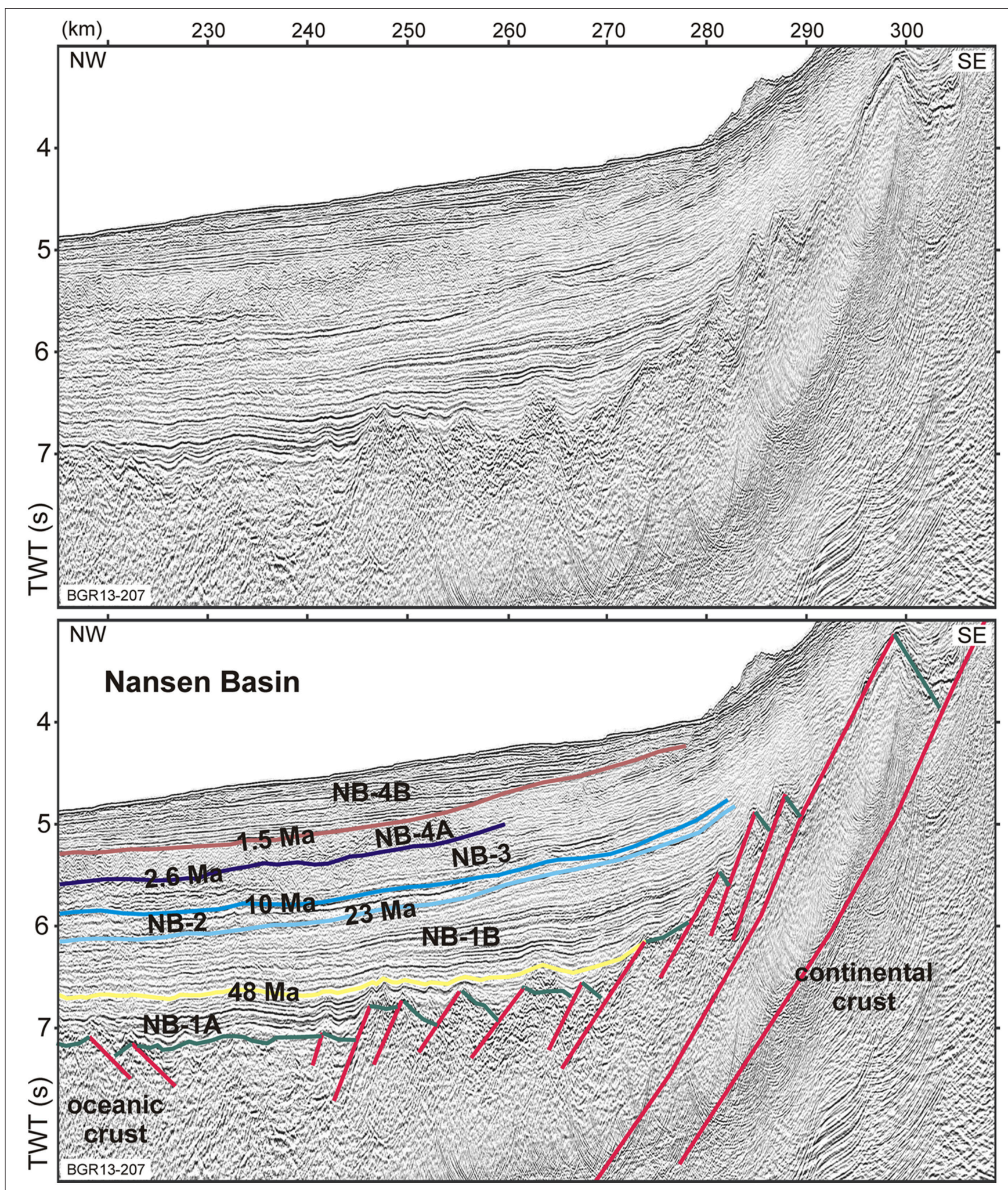

FIGURE 5 | Zoom of the continental margin north of the Barents Shelf shown in Figure 3, indicating a very narrow transition from oceanic to

continental crust. Oldest sedimentary unit is NB-1 A overlying the oceanic crust and infilling small basins formed by disrupted basement blocks (km 245-275). 


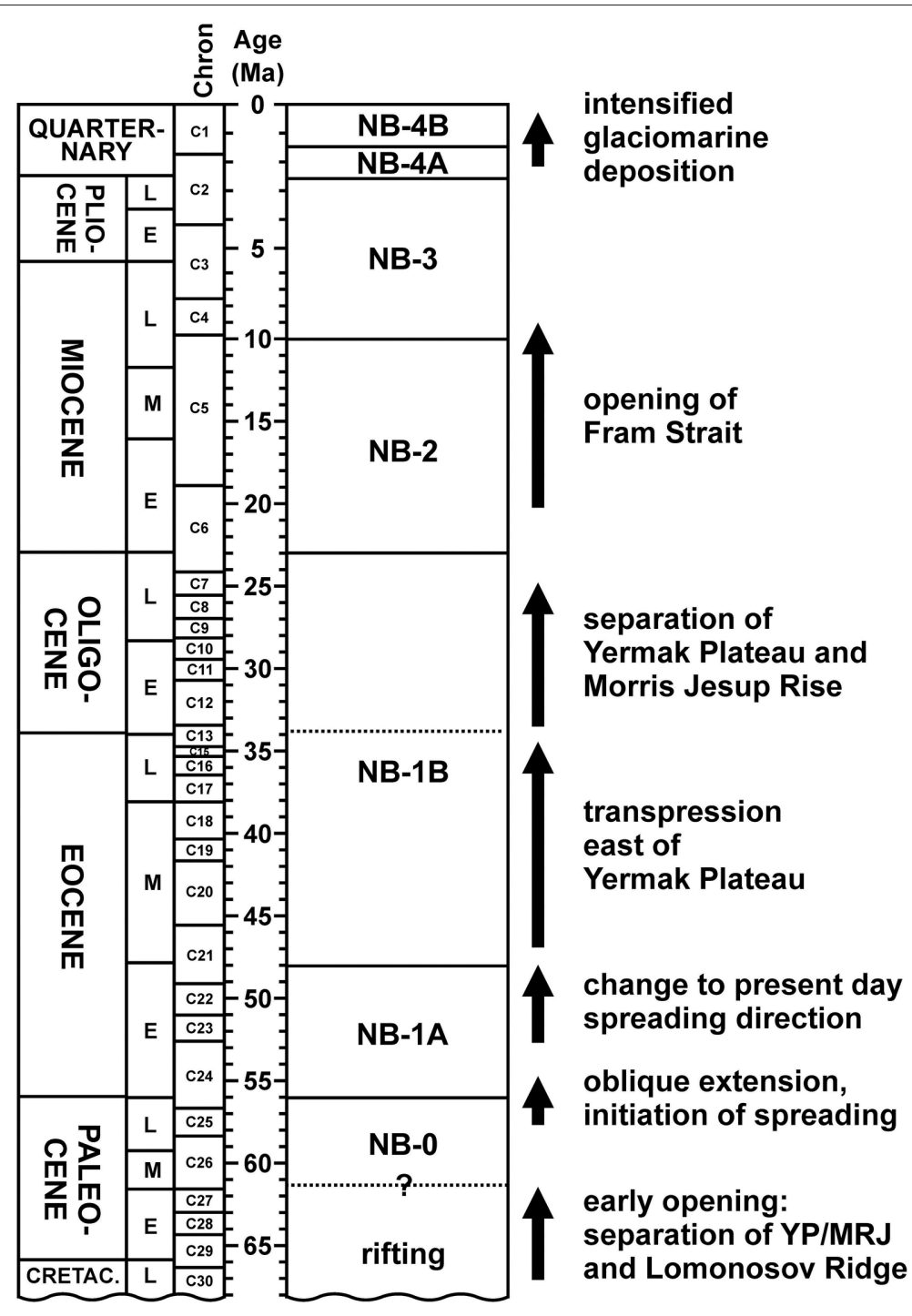

FIGURE 6 | Seismic stratigraphic framework of the westernmost Nansen Basin, and major events affecting the area (modified from Engen et al., 2009). YP, Yermak Plateau; MJR, Morris Jesup Rise.

(Døssing et al., 2013, 2014) and potentially subduction (Brozena et al., 2003), as consequence of the Paleogene northward convergence of Greenland. Plate tectonic models often compensate for the extension in the Labrador Sea and Baffin Bay by invoking a northeastward movement of Greenland. The oldest undisputed seafloor spreading magnetic anomaly in the Labrador Sea is magnetic chron C27 with an age of $\sim 61 \mathrm{Ma}$ (Chalmers and Pulvertaft, 2001) but seafloor spreading may have begun up to 10 My earlier. While the Eurekan N-S shortening is well-documented in Ellesmere Island, North Greenland and western Svalbard, the structural configuration north of Greenland remain unresolved. The North Greenland transform margin province includes sedimentary basins under the Wandel Sea and the Lincoln Sea (Sørensen et al., 2011). Structural analyses within different areas of the Wandel Hav Mobile Belt of northeast Greenland suggest that the main compressive deformation was caused by a comparable dextral transpressive mechanism. According to von Gosen and Piepjohn (2003), it is probable that the Wandel Hav Mobile Belt represents the equivalent of the De Geer Fault Zone along which the Eurasian plate was dextrally displaced with respect to north Greenland. Thus, the relative motion between Greenland and Svalbard, including the Yermak Plateau, was mainly strike-slip with only a small component of compression (Srivastava, 1985). In addition, Tegner et al. (2011) found that the compression associated with the Eurekan deformation had affected the 85-60 Ma volcanic suite at the northern tip of Greenland-thus indicating that the late Cretaceous to Paleocene rifting preceded the predominantly Eocene Eurekan transpressional-compressional deformation. These interpretations correspond well with our findings that 
Paleocene and Eocene compressional tectonics did not extend across the Yermak Plateau into the Eurasian Basin. We link the smaller scale Eocene compressional features, observed in our seismic section (Figure 4), to the northward displacement of the Lomonosov Ridge (Figures 7C,D).

\section{The North Barents Sea Continental Margin}

Continental rifting and the detachment of a narrow and elongated crustal splinter, like the Lomonosov Ridge, from the North Barents Sea continental margin, is not easily explained given the strength of cold continental lithosphere that typically exceeds the available forces. Müller et al. (2001) suggest that prolonged periods of asymmetries in oceanic crustal accretion, as well as the mechanical and thermal effects of excess magmatism, are preconditions for detaching fragments of continental crust. However, as pointed out by Minakov et al. (2013), the magma-starved evolution of the Eurasian Basin implies the occurrence of another mechanism to enable the detachment of the Lomonosov Ridge microcontinent. Their preferred explanation, underpinned by numerical modeling, is a combination of strike-slip deformation and shear heating. These results correspond well with other modeling studies which show that a narrow zone of deformation, of the kind observed along the conjugate Lomonosov Ridge and the North Barents Sea continental margin, indicates highly oblique rifting (e.g., Autin et al., 2010; Brune et al., 2012).

The architecture of the North Barents Sea continental margin with a narrow and steep continent-ocean transition
(Geissler and Jokat, 2004; Minakov et al., 2012, this study), and the mirrored image at the conjugate Eurasian Basin margin of the Lomonosov Ridge (Cochran et al., 2006; Langinen et al., 2009) are also indicative of highly oblique movements during the initial formation of these continental margins, rather than typical magma-poor extension. Our interpretation of an initial rift-axis, highly oblique to the later spreading axis (Figure 7A), is well in accordance with the previous interpretation of initial strike-slip faulting along the North Barents Sea continental margin (Minakov et al., 2013). A transfer fault, segmenting this early rift might have enabled the split off of the Lomonosov Ridge from the present-day North Barents Sea continental margin (Figure 7B). In addition such a setting offers an explanation for the observed narrow continent-ocean transition zone.

\section{The Early Eurasian Basin-a Rift at a High Angle to the Present Day Gakkel Ridge Seafloor Spreading System}

In contrast to earlier interpretations, we suggest that spreading in the Eurasian Basin did not initiate at a triple-junction north of Greenland between North America, Greenland and Eurasia. Our single composite reflection seismic line indicate the presence of a (?) Late Cretaceous to Paleocene rifted continental margin at the NE edge of the Yermak Plateau (and consequently also at the Morris Jesup Rise), and highly oblique deformation at the boundary between the North Barents Sea continental margin to the north of Svalbard and the Eurasian Basin. By acknowledging

\section{A Late Cretaceous? I Paleocene}

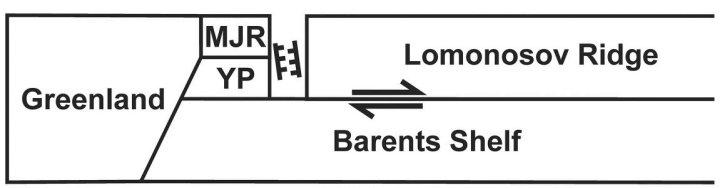

Rifting between YP/MJR and Lomonosov Ridge

B Late Paleocene/Early Eocene (C25?/C24)

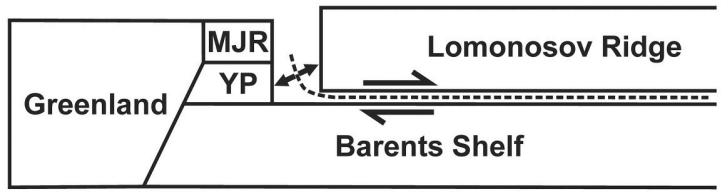

Oblique extension, initiation of spreading

\section{c Eocene (between C24-C15)}

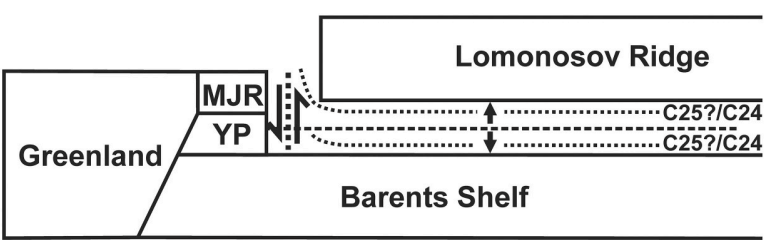

Change to present day spreading direction, transpressive deformation east of YP

\section{Late Eocene (C15)}



End of transpressive deformation east of YP

FIGURE 7 | Sketch depicting the tectonic evolution of the western Eurasian Basin (not to scale). (A) Rifting between Yermak Plateau (YP)/Morris Jesup Rise (MJR) and the Lomonosov Ridge, right-lateral movement between the Barents Shelf and the Lomonosov Ridge (adopted from Minakov et al., 2013). (B) Initiation of spreading, anomalies C25?/C24 are bent northward between YP/MJR and the Lomonosov Ridge. (C) The northward displacement of the Lomonosov Ridge along the Yermak Plateau might have resulted in transpression. (D) The Gakkel Ridge has passed the YP, thus right-lateral movement and transpression stopped. The sketch shows the situation just before break-up of YP and MJR. 
the gravity and magnetic signals running roughly perpendicular to the seafloor spreading fabric along the NE Yermak Plateau and Morris Jesup Rise, we speculate that this is in fact the trend of the rift axis, with the North Barents Sea continental margin being deformed by a rift transform which is highly oblique to the present day rift axis. The bend toward the north in the earliest magnetic isochrons close to the Yermak Plateau, as well as a prominent bend in the magnetic data between the Morris Jesup Rise and the Lomonosov Ridge in the Lincoln Sea (Figure 2B, Brozena et al., 2003; Engen et al., 2008) may be the manifestation of this early extensional direction. The basement below the small basin located between the northeastern Yermak Plateau and the North Barents Sea continental margin (Figure 1) is described as rifted continental crust (Geissler and Jokat, 2004). The timing of crustal thinning in this small basin area is unknown, it could also be related to a later stage of opening of the Eurasian Basin.

Further north, at the transition from the Eurasia to the Amerasian Basin, a crustal-scale wide-angle refraction seismic line confirms a northward shallowing of the Moho from the Lincoln Sea toward the edge of the Lomonosov Ridge (Jackson et al., 2010). Jackson et al. (2010) propose that the thinning was inherited from a rifting event prior to seafloor spreading in the Eurasian Basin. This interpretation of rifting is appealing because it may be correlated with the Late Cretaceous to Paleocene alkaline volcanic suites of northern Canada and north Greenland that probably formed in a failed rift zone preceding seafloor spreading in the Eurasian Basin (Estrada and Henjes-Kunst, 2004; Tegner et al., 2011). Considering an early extensional phase with a trend roughly perpendicular to the present day seafloor spreading fabric in the Eurasian Basin, this speculative rift might be linked to extension in the Lincoln Sea resulting in the deposition of the thick sedimentary successions described by Døssing et al. (2014), and the northward shallowing of the Moho shown by Jackson et al. (2010).

Being constrained by only a single composite reflection seismic line, conclusions about the rift architecture are limited. However, from a geometrical point of view, we suggest the presence of a highly oblique rift in the earliest stages of the Eurasian Basin development, probably without the onset of seafloor spreading. The latter occurred in our view when the stress regime rotated counterclockwise and enabled opening in the present direction.

\section{CONCLUSIONS}

Multichannel reflection seismic data from the NE Yermak Plateau and the North Barents Sea continental margin show an about $80 \mathrm{~km}$ wide continental margin at the NE Yermak Plateau dominated by rotated fault blocks and bounded by major

\section{REFERENCES}

Alvey, A., Gaina, C., Kusznir, N. J., and Torsvik, T. H. (2008). Integrated crustal thickness mapping and plate reconstructions for the high Arctic. Earth Planet. Sci. Lett. 274, 310-321. doi: 10.1016/j.epsl.2008. 07.036 listric normal faults. The corresponding half-grabens are filled with syn-rift sedimentary strata. We interpret this structural setting as the expression of a magma-poor rifted continental margin. This indicates that this portion of the Yermak Plateau is underlain by continental crust, similar to the other portions of the plateau. There are negligible indications for compressional deformation, and we exclude the possibility of subduction in this area. We thus conclude that the Late Paleocene and earlymiddle Eocene compressional deformation well known from North Greenland and Svalbard (Eurekan) did not extend across the Yermak Plateau.

The eastward transition from the rift system into the oceanic Nansen Basin is formed by a basement high, characterized in the seismic data by high impedance reflectors, which is possibly formed by exhumed mantle. At the steep slope of the North Barents Sea continental margin no rift basins are observed and only a comparatively narrow area has been deformed by horizontal extension.

By acknowledging the structural configuration as derived from the MCS data and the potential field data we speculate about the presence of a ?Late Cretaceous to Paleocene rift between the Yermak Plateau and the Lomonosov Ridge, the latter having been still attached to the Eurasian continent. This rift is suggested as striking at a high angle to the present-day seafloor spreading fabric in the Eurasian Basin. We suggest that the initial formation of the Eurasian Basin took place along this rift, between the plateaus of the Morris Jesup Rise-Yermak Plateau and the Lomonosov Ridge, and possibly connected to shallowing of the Moho in the northern Lincoln Sea. Within this hypothesis, the later breakup of the Lomonosov Ridge from the North Barents Sea continental margin initiated by a transform fault, accommodating the extension of the initial oblique rift. So far, this conceptual model remains a working hypothesis, based only on one MCS line and supported by potential field data. Additional data are necessary to confirm the model.

\section{AUTHOR CONTRIBUTIONS}

$\mathrm{KB}, \mathrm{DF}, \mathrm{RL}, \mathrm{BS}, \mathrm{VD}$ : Interpretation, discussions, development of ideas, text. KB: Seismic data processing. BS: Magnetic data processing.

\section{ACKNOWLEDGMENTS}

We thank the crew and Captain of OGS Explora for their professional support during the cruise. The editors Alexey Piskarev and $\varnothing \mathrm{E}$ and three reviewers are thanked for their constructive and helpful comments which greatly improved this manuscript. 
Bronner, A., Sauter, D., Manatschal, G., Peron-Pinvidic, G., and Munschy, M. (2011). Magmatic breakup as an explanation for magnetic anomalies at magmapoor rifted margins. Nat. Geosci. 4, 549-553. doi: 10.1038/ngeo1201

Brozena, J. M., Childers, V. A., Lawver, L. A., Gahagan, L. M., Forsberg, R., Faleide, J. I., et al. (2003). New aerogeophysical study of the Eurasia Basin and Lomonosov Ridge: implications for basin development. Geology 31, 825-828. doi: $10.1130 / \mathrm{g} 19528.1$

Brune, S., Popov, A. A., and Sobolev, S. V. (2012). Modeling suggests that oblique extension facilitates rifting and continental break-up. J. Geophys. Res. 117, B08402. doi: 10.1029/2011jb008860

Chalmers, J. A., and Pulvertaft, T. C. R. (2001). Development of the continental margins of the Labrador Sea: a review. Geol. Soc. Lond. Special Publ. 187, 77-105. doi: 10.1144/gsl.sp.2001.187.01.05

Cochran, J. R., Edwards, M. H., and Coakley, B. J. (2006). Morphology and structure of the Lomonosov Ridge, Arctic Ocean. Geochem. Geophys. Geosyst. 7, Q05019. doi: 10.1029/2005gc001114

Cullen, A., Reemst, P., Henstra, G., Gozzard, S., and Ray, A. (2010). Rifting of the South China Sea: new perspectives. Petroleum Geosci. 16, 273-282. doi: 10.1144/1354-079309-908

Ding, W., Li, J., and Clift, P. D. (2016). Spreading dynamics and sedimentary process of the Southwest Sub-basin, South China Sea: constraints from multichannel seismic data and IODP Expedition 349. J. Asian Earth Sci. 115, 97-113. doi: 10.1016/j.jseaes.2015.09.013

Døssing, A., Hansen, T. M., Olesen, A. V., Hopper, J. R., and Funck, T. (2014). Gravity inversion predicts the nature of the amundsen basin and its continental borderlands near greenland. Earth Planet. Sci. Lett. 408, 132-145. doi: 10.1016/j.epsl.2014.10.011

Døssing, A., Hopper, J. R., Olesen, A. V., Rasmussen, T. M., and Halpenny, J. (2013). New aero-gravity results from the Arctic: linking the latest Cretaceousearly Cenozoic plate kinematics of the North Atlantic and Arctic Ocean. Geochem. Geophys. Geosyst. 14, 4044-4065. doi: 10.1002/ggge.20253

Eldholm, O., Faleide, J. I., and Myhre, A. M. (1987). Continent-ocean transition at the western Barents Sea/Svalbard continental margin. Geology 15, 1118-1122. doi: 10.1130/0091-7613(1987)15<1118:ctatwb > 2.0.co;2

Engen, Ø., Faleide, J. I., and Dyreng, T. K. (2008). Opening of the fram strait gateway: a review of plate tectonic constraints. Tectonophysics 450, 51-69. doi: 10.1016/j.tecto.2008.01.002

Engen, Ø., Gjengedal, J. A., Faleide, J. I., Kristoffersen, Y., and Eldholm, O. (2009). Seismic stratigraphy and sediment thickness of the Nansen Basin, Arctic Ocean. Geophys. J. Int. 176, 805-821. doi: 10.1111/j.1365-246X.2008.04028.x

Estrada, S., and Henjes-Kunst, F. (2004). Volcanism in the Canadian High Arctic related to the opening of the Arctic Ocean. Z. Dtsch. Geol. Ges. 154, 579-603. Available online at: https://www.schweizerbart.de/papers/zdgg_alt/detail/154/ 74983/Volcanism_in_the_Canadian_High_Arctic_related_to_the_opening of_the_Arctic_Ocean

Feden, R. H., Vogt, P. R., and Fleming, H. S. (1979). Magnetic and bathymetric evidence for the "Yermak hot spot" northwest of Svalbard in the Arctic Basin. Earth Planet. Sci. Lett. 44, 18-38. doi: 10.1016/0012-821x(79)90004-9

Franke, D., Barckhausen, U., Baristeas, N., Engels, M., Ladage, S., Lutz, R., et al. (2011). The continent-ocean transition at the southeastern margin of the South China Sea. Mar. Petroleum Geol. 28, 1187-1204. doi: 10.1016/j.marpetgeo.2011.01.004

Franke, D., and Hinz, K. (2005). The structural style of sedimentary basins on the shelves of the Laptev Sea and the western East Siberian Sea, Siberian Arctic. J. Petroleum Geol. 28, 269-286. doi: 10.1111/j.1747-5457.2005.tb00083.x

Franke, D., Savva, D., Pubellier, M., Steuer, S., Mouly, B., Auxietre, J.-L., et al. (2014). The final rifting evolution in the South China Sea. Mar. Petroleum Geol. 58, 704-720. doi: 10.1016/j.marpetgeo.2013.11.020

Gaina, C., Gernigon, L., and Ball, P. (2009). Palaeocene-Recent plate boundaries in the NE Atlantic and the formation of the Jan Mayen microcontinent. J. Geol. Soc. Lond. 166, 601-616. doi: 10.1144/0016-76492008-112

Gaina, C., Werner, S. C., Saltus, R., Maus, S., and the, CAMP-GM GROUP (2011). Circum-Arctic mapping project: new magnetic and gravity anomaly maps of the Arctic. Geol. Soc. Lond. Mem. 35, 39-48. doi: 10.1144/m35.3

Gee, J. S., and Kent, D. V. (2007). "5.12-Source of oceanic magnetic anomalies and the geomagnetic polarity timescale," in Treatise on Geophysics, ed G. Schubert (Amsterdam: Elsevier), 455-507.
Geissler, W. H., and Jokat, W. (2004). A geophysical study of the northern Svalbard continental margin. Geophys. J. Int. 158, 50-66. doi: 10.1111/j.1365246X.2004.02315.x

Geissler, W. H., Jokat, W., and Brekke, H. (2011). The Yermak Plateau in the Arctic Ocean in the light of reflection seismic data-implication for its tectonic and sedimentary evolution. Geophys. J. Int. 187, 1334-1362. doi: 10.1111/j.1365246X.2011.05197.x

Gillard, M., Autin, J., Manatschal, G., Sauter, D., Munschy, M., and Schaming, M. (2015). Tectonomagmatic evolution of the final stages of rifting along the deep conjugate Australian-Antarctic magma-poor rifted margins: constraints from seismic observations. Tectonics 34, 753-783. doi: 10.1002/2015tc003850

Glebovsky, V. Y., Kaminsky, V. D., Minakov, A. N., Merkur'ev, S. A., Childers, V. A., and Brozena, J. M. (2006). Formation of the Eurasia Basin in the Arctic Ocean as inferred from geohistorical analysis of the anomalous magnetic field. Geotectonics 40, 263-281. doi: 10.1134/s0016852106040029

Haupert, I., Manatschal, G., Decarlis, A., and Unternehr, P. (2016). Upper-plate magma-poor rifted margins: stratigraphic architecture and structural evolution. Mar. Petroleum Geol. 69, 241-261. doi: 10.1016/j.marpetgeo.2015.10.020

Hellebrand, E. (2000). "Petrology," in Berichte zur Polarforschung (Reports on Polar Research), The Expedition ARKTIS-XV/2 of'Polarstern'in 1999, ed W. Jokat (Bremerhaven: AWI), 59-70.

Jackson, H. R., Dahl-Jensen, T., and The, L. W. G. (2010). Sedimentary and crustal structure from the Ellesmere Island and Greenland continental shelves onto the Lomonosov Ridge, Arctic Ocean. Geophys. J. Int. 182, 11-35. doi: 10.1111/j.1365-246X.2010.04604.x.

Jackson, H. R., Johnson, G. L., Sundvor, E., and Myhre, A. M. (1984). The Yermak Plateau: formed at a triple junction. J. Geophys. Res. 89, 3223-3232. doi: 10.1029/JB089iB05p03223.

Jakobsson, M., Mayer, L., Coakley, B., Dowdeswell, J. A., Forbes, S., Fridman, B., et al. (2012). The International Bathymetric Chart of the Arctic Ocean (IBCAO) Version 3.0. Geophys. Res. Lett. 39:L12609. doi: 10.1029/2012GL052219

Jokat, W., Geissler, W., and Voss, M. (2008). Basement structure of the north-western Yermak Plateau. Geophys. Res. Lett. 35, 1-6. doi: 10.1029/2007GL032892

Jokat, W., Ickrath, M., and O'Connor, J. (2013). Seismic transect across the Lomonosov and Mendeleev Ridges: constraints on the geological evolution of the Amerasia Basin, Arctic Ocean. Geophys. Res. Lett. 2013, GL057275. doi: 10.1002 /grl.50975

Klimke, J., Franke, D., Gaedicke, C., Schreckenberger, B., Schnabel, M., Stollhofen, H., et al. (in press). How to identify oceanic crust-evidence for a complex break-up in the Mozambique Channel, off East Africa. Tectonophysics 17. doi: 10.1016/j.tecto.2015.10.012

Langinen, A. E., Lebedeva-Ivanova, N. N., Gee, D. G., and Zamansky, Y. Y. (2009). Correlations between the Lomonosov Ridge, Marvin Spur and adjacent basins of the Arctic Ocean based on seismic data. Tectonophysics 472, 309-322. doi: 10.1016/j.tecto.2008.05.029

Lawver, L. A., Gahagan, L. M., and Norton, I. (2011). Chapter 5 Palaeogeographic and tectonic evolution of the Arctic region during the Palaeozoic. Geol. Soc. Lond. Mem. 35, 61-77. doi: 10.1144/m35.5

Lawver, L. A., Grantz, A., and Gahagan, L. M. (2002). Plate kinematic evolution of the present Arctic region since the Ordovician. Geol. Soc. Am. Special Pap. 360, 333-358. doi: 10.1130/0-8137-2360-4.333

Manatschal, G. (2004). New models for evolution of magma-poor rifted margins based on a review of data and concepts from West Iberia and the Alps. Int. J. Earth Sci. 93, 432-466. doi: 10.1007/s00531-004-0394-7

Minakov, A., Faleide, J. I., Glebovsky, V. Y., and Mjelde, R. (2012). Structure and evolution of the northern Barents-Kara Sea continental margin from integrated analysis of potential fields, bathymetry and sparse seismic data. Geophys. J. Int. 188, 79-102. doi: 10.1111/j.1365-246X.2011.05258.x

Minakov, A. N., Podladchikov, Y. Y., Faleide, J. I., and Huismans, R. S. (2013). Rifting assisted by shear heating and formation of the Lomonosov Ridge. Earth Planet. Sci. Lett. 373, 31-40. doi: 10.1016/j.epsl.2013.04.042

Müller, R. D., Gaina, C., Roest, W. R., and Hansen, D. L. (2001). A recipe for microcontinent formation. Geology 29, 203-206. doi: 10.1130/00917613(2001)029<0203:arfmf>2.0.co;2

Peron-Pinvidic, G., Manatschal, G., and Osmundsen, P. T. (2013). Structural comparison of archetypal Atlantic rifted margins: a review 
of observations and concepts. Mar. Petroleum Geol. 43, 21-47. doi: 10.1016/j.marpetgeo.2013.02.002

Riefstahl, F., Estrada, S., Geissler, W. H., Jokat, W., Stein, R., Kämpf, H., et al. (2013). Provenance and characteristics of rocks from the Yermak Plateau, Arctic Ocean: petrographic, geochemical and geochronological constraints. Mar. Geol. 343, 125-145. doi: 10.1016/j.margeo.2013.06.009

Ritzmann, O., and Jokat, W. (2003). Crustal structure of northwestern Svalbard and the adjacent Yermak Plateau: evidence for Oligocene detachment tectonics and non-volcanic breakup. Geophys. J. Int. 152, 139-159. doi: 10.1046/j.1365246X.2003.01836.x

Roeser, H. A., Steiner, C., Schreckenberger, B., and Block, M., (2002). Structural development of the Jurassic Magnetic Quiet Zone off Morocco and identification of Middle Jurassic magnetic lineations. J. Geophys. Res. 107, 2207. doi: 10.1029/2000JB000094

Shephard, G. E., Müller, R. D., and Seton, M. (2013). The tectonic evolution of the Arctic since Pangea breakup: integrating constraints from surface geology and geophysics with mantle structure. Earth Sci. Rev. 124, 148-183. doi: 10.1016/j.earscirev.2013.05.012

Sibuet, J.-C., Srivastava, S., and Manatschal, G. (2007). Exhumed mantle-forming transitional crust in the Newfoundland-Iberia rift and associated magnetic anomalies. J. Geophys. Res. 112, B06105. doi: 10.1029/2005jb003856

Sørensen, K., Gautier, D., Pitman, J., Jackson, H. R., and Dahl-Jensen, T. (2011). Geology and petroleum potential of the Lincoln Sea Basin, offshore North Greenland. Geol. Soc. Lond. Mem. 35, 673-684. doi: 10.1144/m35.44

Srivastava, S. P. (1985). Evolution of the Eurasian Basin and its implications to the motion of Greenland along Nares Strait. Tectonophysics 114, 29-53. doi: 10.1016/0040-1951(85)90006-x

Srivastava, S. P., and Tapscott, C. (1986). "Plate kinematics of the North Atlantic," in The Geology of North America, Vol. M, The Western Atlantic Region. (A Decade of North American Geology), eds B. E. Tucholke and P. R. Vogt (Boulder, CO: Geological Society of America), 379-404.

Taylor, B., Goodliffe, A. M., and Martinez, F. (1999). How continents break up: insights from Papua New Guinea. J. Geophys. Res. 104, 7497-7512.
Tegner, C., Storey, M., Holm, P. M., Thorarinsson, S. B., Zhao, X., Lo, C. H., et al. (2011). Magmatism and Eurekan deformation in the High Arctic Large Igneous Province: 40Ar-39Ar age of Kap Washington Group volcanics, North Greenland. Earth Planet. Sci. Lett. 303, 203-214. doi: 10.1016/j.epsl.2010. 12.047

Tessensohn, F., and Piepjohn, K. (2000). Eocene compressive deformation in Arctic Canada, North Greenland and Svalbard and its plate tectonic causes. Polarforschung 68, 121-124. doi: 10.2312/polarforschung.68.121

Tessensohn, F., Von Gosen, W., Piepjohn, K., Saalmann, K., and Mayr, U. (2008). "Narers transform motion and Eurekan compression along the northeast coast of Ellesmere island," in Geology of Northeast Ellesmere Island Adjacent to Kane Basin and Kennedy Channel, ed U. Mayr (Nunavut: Geological Survey of Canada), 227-243. doi:10.4095/226146

Vogt, P. R., Taylor, P. T., Kovacs, L. C., and Johnson, G. L. (1979). Detailed aeromagnetic investigation of the Arctic Basin. J. Geophys. Res. 84, 1071-1089.

von Gosen, W., and Piepjohn, K. (2003). Eurekan transpressive deformation in the Wandel Hav Mobile Belt (northeast Greenland). Tectonics 22, 1039. doi: $10.1029 / 2001$ tc 901040

Whitmarsh, R. B., Manatschal, G., and Minshull, T. A. (2001). Evolution of magma-poor continental margins from rifting to seafloor spreading. Nature 413, 150-154. doi: 10.1038/35093085

Conflict of Interest Statement: The authors declare that the research was conducted in the absence of any commercial or financial relationships that could be construed as a potential conflict of interest.

Copyright (c) 2016 Berglar, Franke, Lutz, Schreckenberger and Damm. This is an open-access article distributed under the terms of the Creative Commons Attribution License (CC BY). The use, distribution or reproduction in other forums is permitted, provided the original author(s) or licensor are credited and that the original publication in this journal is cited, in accordance with accepted academic practice. No use, distribution or reproduction is permitted which does not comply with these terms. 